Roya Mashadiyeva, Canan Cacina*, Soykan Arikan, Saime Sürmen, Seyda Demirkol, Nihat Aksakal and ilhan Yaylim*

\title{
The effect of survivin gene in breast cancer risk and prognosis
}

\section{Meme kanseri risk ve prognozunda survivin geninin etkileri}

https://doi.org/10.1515/tjb-2021-0051

Received March 13, 2021; accepted June 22, 2021;

published online

\section{Abstract}

Objectives: The accumulation of genetic damages in onset of cancer induce activation of protooncogenes or inactivation of tumor suppressor genes thus cause disruption of the balance between cell proliferation and programmed cell death. As a member of the apoptosis inhibitory protein family (IAP), survivin play important roles in carcinogenesis process. The evidence suggests that polymorphisms located in survivin promoter region may be important in determining genetic susceptibility of cancer. In this study, we aimed to examine a possible role of survivin -31 and $-625 \mathrm{G} / \mathrm{C}$ gene polymorphisms in breast cancer.

Methods: A total of 160 breast cancer cases and 153 healthy controls were genotyped by polymerase chain reaction-restriction fragment length polymorphism (PCR-RFLP) methodology.

\footnotetext{
*Corresponding authors: Canan Cacına and Illhan Yaylım, Department of Molecular Medicine, Aziz Sancar Institute of Experimental Medicine, Istanbul University, Vakif Gureba Cad. Capa 34093, Istanbul, Turkey, Phone: 021241420 00/33329, Fax: 02125324171 E-mail: canancacina@gmail.com (C. Cacına), ilhanyaylim@gmail.com (i. Yaylım)

Roya Mashadiyeva and Saime Sürmen, Department of Molecular Medicine, Aziz Sancar Institute of Experimental Medicine, Istanbul University, Istanbul, Turkey

Soykan Arikan, General Surgery Clinics, Istanbul Training and Research Hospital, Istanbul, Turkey

Seyda Demirkol, Faculty of Engineering and Natural Sciences Molecular Biology and Genetic, Biruni University, Istanbul, Turkey Nihat Aksakal, General Surgery Clinics, Istanbul University Medicine Faculty, Istanbul, Turkey
}

Results: Genotype and allele distributions and of -31 and $-625 \mathrm{G} / \mathrm{C}$ polymorphisms were not significantly different between two groups. However, we observed the carriers of survivin $-625 \mathrm{C} / \mathrm{G}$ polymorphism homozygous genotypes (GG/CC) were the significantly higher in patients with tumor necrosis ( $\mathrm{p}=0.047$ ).

Conclusions: Our results suggest that survivin $-625 \mathrm{C} / \mathrm{G}$ polymorphism may be related with tumor prognosis, but we are opinion of that our result require to be validated in larger samples and further comprehensive research may explore the correlation.

Keywords: breast cancer; cancer risk; genotype; prognosis; survivin.

öz

Amaç: Kanser gelişiminde genetik yapıda meydana gelen değişimlerin birikiminin protoonkogenlerin aktivasyonunu ya da tümör baskılayıcı genlerin inaktivasyonunu uyararak hücre proliferasyonu ile programlanmış hücre ölümü arasındaki dengenin bozulmasına neden olduğu bildirilmiştir. Apoptoz inhibitör protein ailesinin (IAP) bir üyesi olarak survivin, karsinogenez sürecinde önemli rol oynamaktadır. Çeşitli çalışmalar, survivin promoter bölgesinde bulunan polimorfizmlerin, kanserin genetik duyarlılığının belirlenmesinde önemli olabileceğini düşündürmektedir. Bu çalışmada meme kanserli hastalarda survivin -31 ve -625 $\mathrm{G} / \mathrm{C}$ gen polimorfizmlerinin olası etkilerinin incelenmesi amaçlanmıştır.

yöntemler: Çalışmada 160 meme kanseri vakası ile 153 sağlıklı kontrol grubu, Polimeraz Zincir ReaksiyonRestriksiyon Uzunluk Polimorfizmi (PCR-RFLP) metodolojisi kullanılarak genotiplendirildi.

Bulgular: Araştırmamız sonucunda -31 ve $-625 \mathrm{G} / \mathrm{C}$ polimorfizm genotip dağılım ve allel frekansları açısından 
karşılaştırıldığında hasta ve kontrol grupları arasında istatistiksel olarak anlamlı bir fark gözlenmemiştir. Ancak, survivin $-625 \mathrm{C} / \mathrm{G}$ polimorfizm homozigot (GG/CC) genotipi tümör nekrozu olan hastalarda istatistiksel olarak yüksek oranda saptanmıştır ( $\mathrm{p}=0.047$ ).

Sonuç: Çalışma bulgularımı, survivin $-625 \mathrm{C} / \mathrm{G}$ polimorfizminin tümör prognozu ile ilişkili olabileceğini düşündürmektedir. Ancak sonucumuzun daha büyük örnek gruplarında doğrulanması gerektiğini ve bu alanda yapılacak daha kapsamlı araştırmalarda değerlendirilebileceği kanaatindeyiz.

Anahtar kelimeler: meme kanseri; survivin; genotip; prognoz; kanser riski.

\section{Introduction}

Breast cancer is the most frequently diagnosed malignancy and is known as a highly heterogeneous disease [1]. The mutual impact of genetic susceptibility and environmental factors such as overweight, physical inactivity, alcohol consumption, taking hormone-replacement therapy, menstrual cycles are associated with breast cancer risk and development $[1,2]$. Apoptosis or programmed cellular death process is described as a molecular mechanism which induces embryonic development and maintenance normal cell turnover [3]. Increasing evidence indicates that impairment of apoptosis-related pathways promotes several diseases including cancer, through the accumulation of transforming mutation also enhance autoimmune and immunodeficiency diseases, and neurodegenerative disorders [3-5]. The apoptosis signaling pathway can be blocked by a family of proteins with several biological functions which are defined as inhibitor of apoptosis proteins (IAPs) through direct inhibition of caspases [6]. Survivin antiapoptotic molecule is a member of IAP family that is usually expressed in the embryonic tissues in the developmental stages and appears a substantial protein for the regulation of mitosis and apoptosis [7]. Recent investigations indicate that promoter regions including cell cycle-dependent element (CDE) and the cell cycle genes homology region (CHR) that are upstream of the transcription start site responsible for regulating the expression of survivin during G2/M phase of cell cycle $[8,9]$. The researchers reported that survivin play crucial role in the mitotic progression by regulation of microtubule stability, and expression of survivin profile in tumors is related to decreased apoptotic cell death and increased resistance to chemotherapy [10, 11].

Survivin, also called as BIRC5 gene contains four exons and three introns span approximately 14,796 nucleotides located on human chromosome 17q25, consists of 142 amino acid residues [11, 12]. The well-known promoter polymorphism of the survivin gene, that is, the nucleotide substitution from $G$ to $C$ (rs9904341) corresponding to position -31 is located inside the CDE/CHR binding site and current evidence shows that this single nucleotide polymorphism alters the binding sites and induce overexpression of survivin at both mRNA and protein levels [12-14]. There is also $-625 \mathrm{G} / \mathrm{C}$ (rs;8073069) polymorphism in the promoter region may affects the genetic susceptibility to cancer by alteration survivin function and expression $[14,15]$. Although the effects of survivin polymorphism have been tested in different types of malignancy there are limited number of studies that subjected to survivin gene $(-625,31 \mathrm{G} / \mathrm{C})$ results. This study was aimed to examine a possible role of some critical functional polymorphisms in survivin gene on breast cancer risk and progression using a case-control designed study.

\section{Materials and methods}

\section{Study groups}

This study was conducted on 160 breast cancer patients and 153 controls to investigate survivin polymorphisms. All patients consisted of individuals who were followed up for three years at the Istanbul Training and Research Hospital, General Surgery Clinic. The patients had not started any treatment (chemotherapy or radiotherapy) and the control subjects had no signs of malignancy and preferably had without a family history of cancer. The healthy controls were randomly chosen from the volunteers. Their blood samples were obtained with the informed consent of the participants and approval of the Ethics Committee of the İstanbul Faculty of Medicine.

\section{Genomic DNA extraction}

By using the simple salting-out method, high-quality gDNA extraction was carried out from $10 \mathrm{~mL}$ of fresh peripheral blood samples [16]. Briefly, this method is based on isolation of leukocytes from anticoagulated blood, digestion with proteinase $\mathrm{K}$, protein precipitation with high salt concentration and DNA precipitation with ethanol. To assess the quantity and quality of DNA yield, we measured samples at 260/280 nm ratio absorbance spectrum using the NanoDrop spectrophotometer (Thermo Fisher Scientific).

\section{Genotyping with PCR-RFLP}

Two single nucleotide polymorphisms (SNPs) ( -31 and $-625 \mathrm{G} / \mathrm{C}$ ) of survivin gene were evaluated by polymerase chain reaction-restriction fragment length polymorphism (PCR-RFLP). The regions were amplified from 50-100 ng DNA using previously reported specific primers. To detect -31 and $-625 \mathrm{G} / \mathrm{C}$ polymorphisms, the primer pairs were used 5'-GTTCTTTGAAAGCAGTCGAG-3' (forward), 5'- GCCAGTTCTTGAATG 
TAGAG-3' (reverse), 5'-TGTTCATTTGTCCTTCATGCGC-3' (forward) and 5'-CCAGCCTAGGCAACAAGAGCAA-3' (reverse), respectively. The PCR was performed in a final volume of $24 \mu \mathrm{L}$ containing $0.20 \mathrm{mM}$ of dNTP ready mix, $10 \mathrm{pmol}$ of forward and reverse primers specific to the region, $2.5 \mathrm{mM} \mathrm{MgCl}_{2}$ buffer, and Taq polymerase (Fermentas, Vilnius, Lithuania). The cycling conditions involved these steps; initial denaturation at $95^{\circ} \mathrm{C}$ for $5 \mathrm{~min}$, followed by 30 cycles of denaturation at $95^{\circ} \mathrm{C}$ for $30 \mathrm{~s}$, annealing at appropriate temperatures for $45 \mathrm{~s}$, at $72{ }^{\circ} \mathrm{C}$ for $60 \mathrm{~s}$ and a final elongation at $72{ }^{\circ} \mathrm{C}$ for $5 \mathrm{~min}$. For genotyping of $-31 \mathrm{G} / \mathrm{C}$ polymorphism, the digestion of amplified products was performed at $37{ }^{\circ} \mathrm{C}$ overnight with EC0109I restriction enzyme (MBI Fermentas). The digested PCR products were determined by electrophoresis on $2 \%$ agarose gel-stained containing ethidium bromide, visualized under UV light using EL LOGIC 100 Imaging System (KODAK) and its soft-ware. The CC genotype was represented by a DNA band of sizes of $341 \mathrm{bp}$ and the GG genotype was represented by DNA fragments of sizes of 236 and $105 \mathrm{bp}$, whereas the heterozygotes showed a combination of both alleles $(341,236,105 \mathrm{bp}$ ) (Figure 1) [17]. For genotyping of $-625 \mathrm{G} / \mathrm{C}$ polymorphism, BstUI restriction enzyme (MBI Fermentas) was used to digest $10 \mu \mathrm{L}$ PCR product for $2 \mathrm{~h}$ at $37^{\circ} \mathrm{C}$. To visualize of fragments, digestion products were separated by electrophoresis on agarose gel with ethidium bromide staining for $30 \mathrm{~min}$ [18]. The homozygous GG genotype was digested and yielded two bands of 104 and $21 \mathrm{bp}$, heterozygous GC genotype yielded three bands 125, 104, and $21 \mathrm{bp}$ and the homozygous CC genotype was undigested and yielded a single $125 \mathrm{bp}$ band (Figure 2).

\section{Statistical analysis}

The data obtained were analyzed using the statistics program SPSS software package (revision 11.5 SPSS Inc., Chicago, IL, USA). Chi-square $\left(\chi^{2}\right)$ test was performed to determine the significant differences in genotype or allele distribution between cases and controls for each polymorphism. In addition, a multivariate logistic regression model adjusted for age was used to examine the effects of survivin gene polymorphisms on breast cancer risk and to calculate the odds ratio (OR) and 95\% confidence interval (CI). p-Value $<0.05$ indicates statistical significance. Linkage disequilibrium between -31 and $-625 \mathrm{G} / \mathrm{C}$ polymorphisms was also estimated utilizing Haplowiew program 4.2 (http://www.broad.mit.edu/mpg/haploview/documentation.php). LD plot and haplotype frequencies were generated from the genotype data.

\section{Results}

According to the demographic variables, the mean age of the control group was $50.53 \pm 13.9$ and the patient group was $54.4 \pm 12.2$. We could not observe a statistically significant difference between patient and control groups by the terms of age parameter $(\mathrm{p}=0.057)$. The clinical and pathological characteristics of our patients were shown in Table 1.
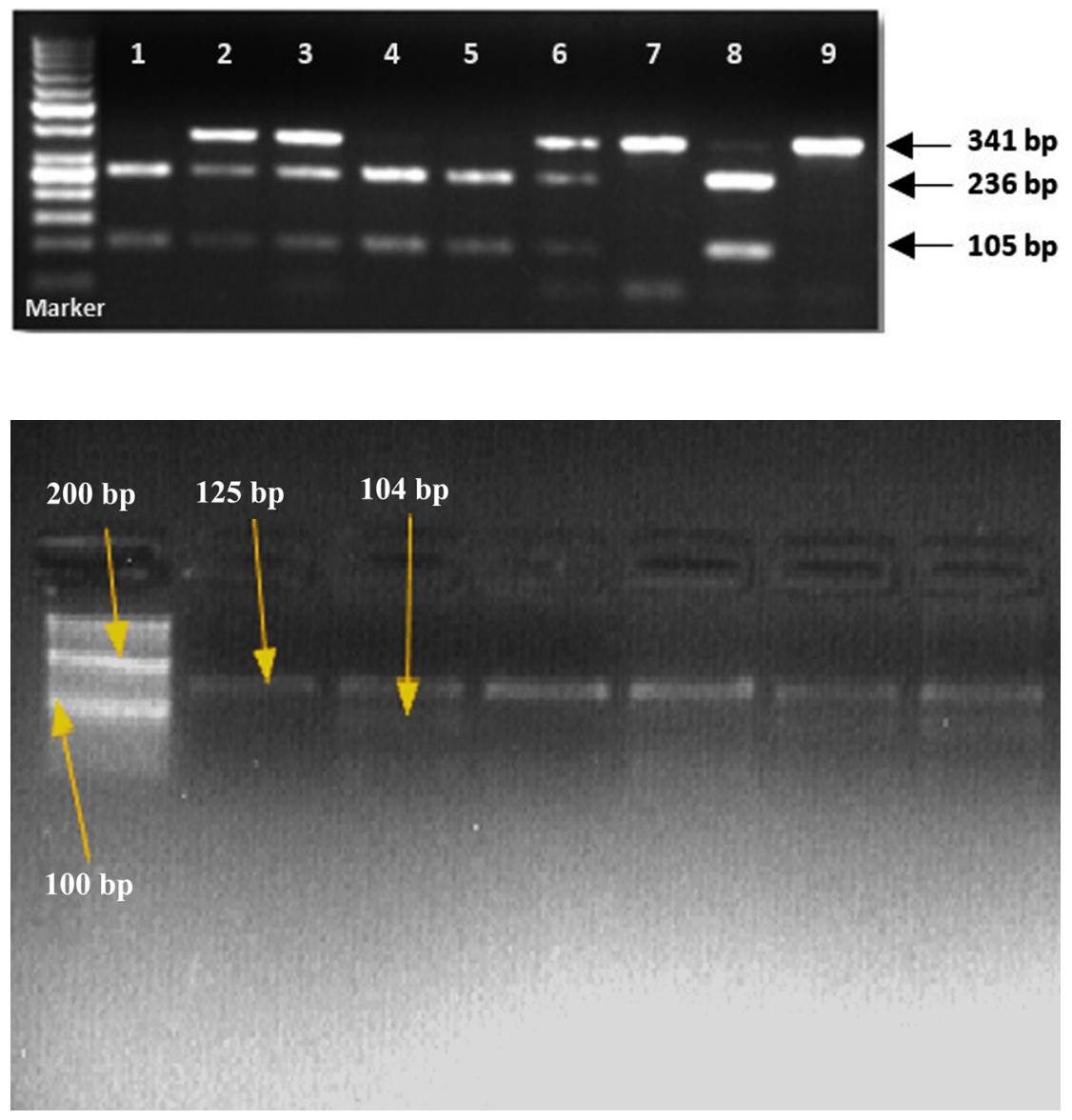

Figure 1: Genotyping of survivin promoter $-31 \mathrm{G} / \mathrm{C}$ polymorphism.

Figure 2: Genotyping of survivin promoter $-625 \mathrm{C} / \mathrm{G}$ polymorphism. 
Table 1: Characteristic distribution of breast cancer patients.

\begin{tabular}{|c|c|}
\hline Characteristic & $\%$ \\
\hline \multicolumn{2}{|l|}{ Tumor type } \\
\hline Invasive ductal carcinoma & 82.2 \\
\hline Invasive lobular & 6.3 \\
\hline Combine type & 7.3 \\
\hline \multicolumn{2}{|l|}{ Familiar history of cancer } \\
\hline Present & 30.4 \\
\hline Absent & 69.6 \\
\hline \multicolumn{2}{|c|}{ First degree breast Ca case in the family } \\
\hline Present & 20.2 \\
\hline Absent & 79.8 \\
\hline \multicolumn{2}{|l|}{ Menopause status } \\
\hline Premenopause & 36.4 \\
\hline Post-menopause & 62.6 \\
\hline \multicolumn{2}{|l|}{ Differentiation } \\
\hline Low & 11.8 \\
\hline Middle & 44.1 \\
\hline High & 44.1 \\
\hline \multicolumn{2}{|l|}{ Comedo } \\
\hline Present & 15.9 \\
\hline Absent & 84.1 \\
\hline \multicolumn{2}{|l|}{ Tumor stages } \\
\hline$T 1$ & 37.3 \\
\hline$T 2$ & 45.2 \\
\hline$T 3$ & 12.7 \\
\hline T4 & 4.8 \\
\hline \multicolumn{2}{|l|}{ Lymph node metastasis } \\
\hline NO & 40.5 \\
\hline N1 & 35.7 \\
\hline N2 & 18.3 \\
\hline N3 & 5.6 \\
\hline \multicolumn{2}{|l|}{ Distant metastasis } \\
\hline Present & 11.1 \\
\hline Absent & 88.9 \\
\hline \multicolumn{2}{|l|}{ Prinodal invasion } \\
\hline Present & 33.6 \\
\hline Absent & 66.4 \\
\hline \multicolumn{2}{|l|}{ Estrogen receptor } \\
\hline Present & 78.8 \\
\hline Absent & 21.2 \\
\hline \multicolumn{2}{|l|}{ Progesterone receptor } \\
\hline Present & 78.3 \\
\hline Absent & 21.7 \\
\hline \multicolumn{2}{|l|}{ Capsular invasion } \\
\hline Present & 32.1 \\
\hline Absent & 67.9 \\
\hline
\end{tabular}

The distributions of genotype and allelic frequency of survivin $-31,-625 \mathrm{G} / \mathrm{C}$ polymorphisms in our patients and controls were demonstrated in Table 2. Survivin promoter $-31 \mathrm{C} / \mathrm{G}$ polymorphism GG, GC, CC genotype frequencies were observed as $29.4,54,16.7 \%$ in cases and $40.3,46.3,13.4 \%$ in the control group, respectively. In genotype distribution, GC genotype was higher in patients compared to controls, but this data was not statistically significant $(\mathrm{p}=0.179)$ (Table 2). When allele frequencies of survivin promoter $-31 \mathrm{C} / \mathrm{G}$ gene polymorphism were evaluated, $\mathrm{C}$ allele frequency was higher in breast cancer patients (43.65\%) compared to the control group (36.57\%), $\mathrm{G}$ allele frequency was lower in the breast cancer group (56.35\%) than the healthy group (63.43\%), but no statistically significant difference was observed. When our study group was evaluated by the terms of genotype distribution, survivin $-625 \mathrm{C} / \mathrm{G}$ gene polymorphism GC genotype carrying status was higher in patients with breast cancer (33.3\%) compared to controls (22.4\%). We also found that the survivin $-625 \mathrm{C} / \mathrm{G}$ gene polymorphism $\mathrm{C}$ allele frequency was higher in patients $(31.75 \%)$ but there were no statistically significant differences in the genotypes and allele frequencies of survivin $-31 \mathrm{C} / \mathrm{G}$ between patients with breast cancer and healthy group $(\mathrm{p}=0.140)$ (Table 3$)$.

The survivin $-31,-625 \mathrm{C} / \mathrm{G}$ genotypes were analyzed according to histopathological findings of breast cancer patients such as tumor stage, presence of nodal metastasis, distant metastasis, differentiation, estrogen receptor, progesterone receptor, capsule invasion, perineural invasion, genotype distribution and angiolymphatic invasion and perinodal invasion. The only difference between

Table 2: Distribution of survivin promotor $-31 \mathrm{C} / \mathrm{G}$ polymorphism results of breast cancer patients and controls by genotype and alleles.

\begin{tabular}{lrrr}
\hline Survivin promotor $-\mathbf{3 1} \mathbf{C} \boldsymbol{} \mathbf{G}$ & Patient & Control & p-Value \\
\hline Genotypes & $\mathrm{n}, \%$ & $\mathrm{n}, \%$ & \\
GG & $37(29.4)$ & $54(40.3)$ & 0.179 \\
GC & $68(54)$ & $62(46.3)$ & \\
CC & $21(16.7)$ & $18(13.4)$ & \\
Alleles & & & \\
G & $142(56.35)$ & $170(63.43)$ & 0.099 \\
C & $110(43.65)$ & $98(36.57)$ & \\
\hline
\end{tabular}

Table 3: Distribution of survivin $-625 \mathrm{C} / \mathrm{G}$ polymorphism results of breast cancer patients and controls by genotype and alleles.

\begin{tabular}{lrrr}
\hline Survivin-625 C/G & Patient & Control & p-Value \\
\hline Genotypes & $\mathrm{n}, \%$ & $\mathrm{n}, \%$ & \\
CC & $19(15.1)$ & $25(18.7)$ & 0.140 \\
GC & $42(33.3)$ & $30(22.4)$ & \\
GG & $65(51.6)$ & $79(59)$ & \\
Alleles & & & \\
C & $80(31.75)$ & $80(29.85)$ & 0.640 \\
G & $172(68.25)$ & $188(70.15)$ & \\
\hline
\end{tabular}


patients' clinicopathologic parameters and the presence of survivin $-625 \mathrm{C} / \mathrm{G}$ polymorphism the homozygous variants (GG/CC) was the significantly higher in patients with tumor necrosis $(p=0.047)$. We also couldn't find any other significant relation between all of genotypes distribution, allel frequency and these prognostic parameters (data not shown) ( $p>0.05)$.

To evaluate the combined effect of survivin SNPs on breast cancer development, the haplotype frequencies were calculated. As shown in Figure 3 lower LD was found between -31 and $-625 \mathrm{G} / \mathrm{C}$ in survivin polymorphisms. The analysis of $\mathrm{LD}$ for the two loci in the survivin gene showed that the $\mathrm{D}^{\prime}$ value for linkage between rs8073069: $-625 \mathrm{G} / \mathrm{C}$ and rs9904341: $-31 \mathrm{G} / \mathrm{C}$ loci was $0.23\left(\mathrm{r}^{2}=0.016\right)$. No significant relationship was found in the distribution of survivin haplotypes between cases and controls. The estimated haplotypes and their frequencies were given in Table 4 (Figure 3).

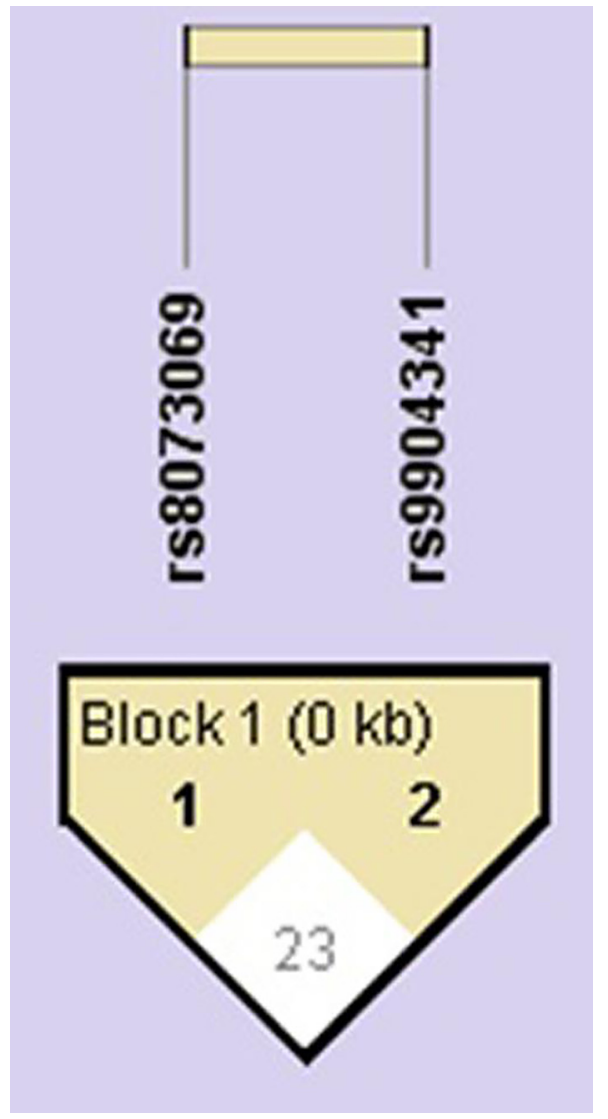

Figure 3: LD block consisting of rs8073069 and rs9904341. $D^{\prime}: 0.23, L O D=1.09, r^{2}=0.016 D^{\prime}$ indicates a normalized measure of linkage disequilibrium between the two loci and $r^{2}$ indicates the correlation coefficient between the two loci.

\section{Discussion}

Breast cancer is the most commonly diagnosed malignancy and one of the leading cancer-related deaths in women worldwide $[1,19]$. Apoptosis has a central role in providing cellular homeostasis, which includes cellular events such as cell proliferation, and differentiation and dysregulation of apoptosis is the important factor related with the poor prognosis of breast cancer $[3,20]$.

IAPs are known to inhibit apoptosis by increasing cell survival and promote genetic changes and may cause to uncontrolled cell growth and tumor progression during the oncogenesis process $[5,21]$. Survivin, defined as a member of the IAP family and the overexpression of this antiapoptotic molecule has been shown to be related with different human cancer types and altered expressions correlated with disease prognosis or response to treatment; they suggest also may become a biomarker for cancer [22]. The survivin promoter side comprises a binding motif for the cell cycle-dependent elements/cell cycle homology region (CDE/CHR). The promoter polymorphism (-31 G/C; rs9904341) of survivin has been reported to be the most extensively investigated SNP [23].

Several clinical and experimental studies reported that the single nucleotide polymorphism (SNP; -31 G/C) alters the binding sites for CDE/CHR and induces pro tein levels and expression of survivin profile. The -31 and $-625 \mathrm{C} / \mathrm{G}$ polymorphisms has been investigated in various types of cancer, including esophageal cancer and colorectal cancer [13-15]. L. Qin and T. Yu et al. performed a case-control study to reveal the association between survivin rs $9904341 \mathrm{G} / \mathrm{C}$ polymorphism and the pancreatic cancer risk. A total of 261 patients with pathologically confirmed pancreatic cancer and 224 control cases were included in the study. rs $9904341 \mathrm{G} / \mathrm{C}$ polymorphisms were evaluated by PCR-RFLP. The patients with pancreatic cancer had higher smoking status, a family history of cancer, and diabetes mellitus [24]. As a result of

Table 4: Haplotype frequencies of the two investigated survivin polymorphisms in breast cancer patients.

\begin{tabular}{lrrrr}
\hline $\begin{array}{l}\text { rs8073069/ } \\
\text { rs9904341 }\end{array}$ & Frequency & $\begin{array}{r}\text { Patient, control } \\
\text { ratio }\end{array}$ & $X^{2}$ & $\begin{array}{r}\mathrm{p}- \\
\text { Value }\end{array}$ \\
\hline$G G$ & 0.386 & $0.350,0.419$ & 2.677 & 0.10 \\
& $(30.7 \%)$ & & & \\
GC & 0.307 & $0.333,0.282$ & 1.584 & 0.20 \\
& $(38.6 \%)$ & & & \\
CG & 0.213 & $0.214,0.211$ & 0.006 & 0.93 \\
& $(21.3 \%)$ & & & \\
CC & $0.095(9.5 \%)$ & $0.104,0.087$ & 0.395 & 0.52 \\
\hline
\end{tabular}


multivariate logistic regression analysis, they reported that the carrying of the CC genotype was significantly correlated with an elevated risk of pancreatic cancer compared to the GG genotype [24]. Similarly, Chen et al. were observed the CC/GC genotypes significantly associated with the prostate cancer risk [25]. In another study, the promoter survivin $-31 \mathrm{G} / \mathrm{C}$ polymorphism was analyzed in 312 patients with sporadic colorectal cancer cases and 362 healthy individuals. They reported that in carriers of the -31 CC genotype, the expression of mRNA survivin levels was 1.6-fold higher compared to cases with -31 and $-31 \mathrm{GC}$ genotypes. It was concluded that the survivin -31 CC genotype might be related with colorectal cancer risk [26]. In a study conducted in the Brazilian population, the $-31 \mathrm{G} / \mathrm{C}$ survivin promoter polymorphism $\mathrm{C}$ allele was observed as a risk factor for gastric cancer [27]. Rasool et al. were studied the $-31 \mathrm{G} / \mathrm{C}$ single nucleotide polymorphism in the 190 breast cancer patients 200 healthy control. As a result of the analysis, the researchers concluded that the homozygous CC genotype may be a risk for breast cancer development [28].

Several nucleotide polymorphisms are defined in the survivin gene regions. Molecular epidemiological studies have examined the effect of survivin $-625 \mathrm{C} / \mathrm{G}$ polymorphism on different cancer types. One study showed that survivin overexpression due to the $\mathrm{p} 53$ mutation and the presence of the $\mathrm{C}$ allele may increase the risk of esophageal cancer [29]. Similarly, another case-control study which was performed by Yang revealed that the survivin promoter $-625 \mathrm{C} / \mathrm{G}$ polymorphism associated with predisposition to ESCC in the Chinese population by affecting survivin expression [15]. In present study, allele frequencies of survivin $-625 \mathrm{C} / \mathrm{G}$ gene polymorphism were evaluated, and we detected the $\mathrm{C}$ allele frequency was higher in patients with breast cancer compared to the control group, but no statistical significance data was found. When we performed stratification analyses by regarding tumor characteristics, the homozygous variant (GG, CC) genotype of survivin $-625 \mathrm{C} / \mathrm{G}$ polymorphism was detected at higher frequency in breast cancer patients with tumor necrosis. Some meta-analyses have been conducted to reveal the relationship of survivin -31 and $-625 \mathrm{C} / \mathrm{G}$ polymorphisms with cancer risk. According to ethnicity subgroup analysis, $\mathrm{Zhu}$ et al. reported that $-31 \mathrm{G} / \mathrm{C}$ SNP was associated with an increased tumor risk only in Asians while there was no significant association in terms of tumor risk for this SNP in Caucasian and mixed populations [30]. Another meta-analysis examining five different SNPs in the survivin gene supports the finding that $-31 \mathrm{G} / \mathrm{C}$ polymorphism significantly increases cancer risk in the Asian population while suggests no significant relation between $-625 \mathrm{C} / \mathrm{G}$ and cancer risk due to the low data volume [31].

In conclusion, the current study was designed to investigate the relationship between the survivin -31 and $-625 \mathrm{C} / \mathrm{G}$ functional polymorphisms and breast cancer risk. There was no significant difference between genotype and allele frequencies when patient and control groups were compared. However, the homozygous (GG, CC) genotypes of survivin $-625 \mathrm{C} / \mathrm{G}$ polymorphism in breast cancer patients were detected at higher frequency in cases with tumor necrosis and this might be related to disease progression. The present study has some limitations for the number of cases and controls. However, we have chosen our group of patients according to strict criteria. If these findings are confirmed in larger patient groups may have a clinical impact in the assessment of the cancer risk, thus opening new perspectives for the investigations of genetic features underlying the mechanisms of breast cancer.

Research funding: This study was funded by grants from the Scientific Research Projects Coordination Unit of Istanbul University (Project No: TYL-2017-22459).

Conflict of interests: The authors declare that there is no conflict of interests.

Ethical approval: The present study was approved by the Ethical Committee of the Istanbul Faculty of Medicine.

\section{References}

1. Martin AM, Weber BL. Genetic and hormonal risk factors in breast cancer. J Natl Cancer Inst 2000;92:1126-35.

2. Weiderpass E, Meo M, Vainio H. Risk factors for breast cancer, including occupational exposures. Health Saf Work 2011;2:1-8.

3. Elmore S. Apoptosis: A review of programmed cell death. Toxicol Pathol 2007;35:495-516.

4. Favaloro B, Allocati N, Graziano V, Di Ilio C, De Laurenzi V. Role of apoptosis in disease. Aging (Albany NY) 2012;4:330-49.

5. Melet A, Song K, Bucur O, Jagani Z, Grassian AR, Khosravi-Far R. Apoptotic pathways in tumor progression and therapy. Adv Exp Med Biol 2008;615:47-79.

6. Berthelet J, Dubrez L. Regulation of apoptosis by inhibitors of apoptosis (IAPs). Cells 2013;2:163-87.

7. Mita AC, Mita MM, Nawrocki ST, Giles FJ. Survivin: key regulator of mitosis and apoptosis and novel target for cancer therapeutics. Clin Canc Res 2008;14:5000-5.

8. Otaki M, Hatano M, Kobayashi K, Ogasawara T, Kuriyama T, Tokuhisa T. Cell cycle-dependent regulation of TIAP/m-survivin expression. Biochim Biophys Acta 2000;1493:188-94.

9. Li F, Ambrosini G, Chu EY, Plescia J, Tognin S, Marchisio PC, et al. Control of apoptosis and mitotic spindle checkpoint by survivin. Nature 1998;396:580-4. 
10. Giodini A, Kallio MJ, Wall NR, Gorbsky GJ, Tognin S, Marchisio PC, et al. Regulation of microtubule stability and mitotic progression by survivin. Canc Res 2002;62:2462-7.

11. Garg H, Suri P, Gupta JC, Talwar GP, Dubey S. Survivin: a unique target for tumor therapy. Canc Cell Int 2016;16:49.

12. Upadhyay R, Khurana R, Kumar S, Ghoshal UC, Mittal B. Role of survivin gene promoter polymorphism $(-31 \mathrm{G}>\mathrm{C})$ in susceptibility and survival of esophageal cancer in northern India. Ann Surg Oncol 2011;18:880-7.

13. Li XB, Li SN, Yang ZH, Cao L, Duan FL, Sun XW. Polymorphisms of survivin and its protein expression are associated with colorectal cancer susceptibility in Chinese population. DNA Cell Biol 2013;32: 236-42.

14. Xu Y, Fang F, Ludewig G, Jones G, Jones D. A mutation found in the promoter region of the human survivin gene is correlated to overexpression of survivin in cancer cells. DNA Cell Biol 2004;23: 527-37.

15. Yang X, Xiong G, Chen X, Xu X, Wang K, Fu Y, et al. Polymorphisms of survivin promoter are associated with risk of esophageal squamous cell carcinoma. J Canc Res Clin Oncol 2009;135:1341-9.

16. Miller SA, Dykes DD, Polesky HF. A simple salting out procedure for extracting DNA from human nucleated cells. Nucleic Acids Res 1988;16:1215.

17. Borbély AA, Murvai M, Szarka K, Kónya J, Gergely L, Hernádi Z, et al. Survivin promoter polymorphism and cervical carcinogenesis. J Clin Pathol 2007;60:303-6.

18. Han CH, Wei Q, Lu KK, Liu Z, Mills GB, Wang LE. Polymorphisms in the survivin promoter are associated with age of onset of ovarian cancer. Int J Clin Exp Med 2009;2:289-99.

19. Fitzmaurice C, Dicker D, Pain A, Hamavid H, Moradi-Lakeh M, et al, Global Burden of Disease Cancer Collaboration. The global burden of cancer 2013. JAMA Oncol 2015;1:505-27.

20. Wang S, Bai L, Lu J, Liu L, Yang CY, Sun H. Targeting inhibitors of apoptosis proteins (IAPs) for new breast cancer therapeutics. J Mammary Gland Biol Neoplasia 2012;17:217-28.
21. Lopez J, Meier P. To fight or die - inhibitor of apoptosis proteins at the crossroad of innate immunity and death. Curr Opin Cell Biol 2010;22:872-81.

22. Johnson ME, Howerth EW. Survivin: a bifunctional inhibitor of apoptosis protein. Vet Pathol 2004;41:599-607.

23. Yazdani N, Sayahpour FA, Haghpanah V, Amiri P, Shahrabi-Farahani $M$, Moradi M, et al. Survivin gene polymorphism association with papillary thyroid carcinoma. Pathol Res Pract 2012;208:100-3.

24. Qin L, Yu T. Association between rs $9904341 \mathrm{G}<\mathrm{C}$ gene polymorphism and susceptibility to pancreatic cancer in a Chinese population. Genet Mol Res 2015;14:5197-202.

25. Chen J, Cui X, Zhou H, Qin C, Cao Q, Ju X, et al. Functional promoter $-31 \mathrm{G} / \mathrm{C}$ variant of Survivin gene predict prostate cancer susceptibility among Chinese: a case control study. BMC Canc 2013;13:356.

26. Gazouli M, Tzanakis N, Rallis G, Theodoropoulos G. Survivin -31 $\mathrm{G} / \mathrm{C}$ promoter polymorphism and sporadic colorectal cancer. Int J Colorectal Dis 2009;24:145-50.

27. Borges Bdo N, Burbano RR, Harada ML. Survivin -31 C/G polymorphism and gastric cancer risk in a Brazilian population. Clin Exp Med 2011;11:189-93.

28. Rasool I, Afroze D, Wani KA, Yousuf A, Bhat IA, Rah B, et al. Role of the functional polymorphism of survivin gene $(-31 \mathrm{G} / \mathrm{C})$ and risk of breast cancer in a North Indian population. Clin Breast Canc 2018;18:e671-6.

29. Yang X, Xiong G, Chen X, Xu X, Wang K, Fu Y, et al. Survivin expression in esophageal cancer: correlation with p53 mutations and promoter polymorphism. Dis Esophagus 2009;22:223-30.

30. Zhu Y, Li Y, Zhu S, Tang R, Liu Y, Li J. Association of survivin polymorphisms with tumor susceptibility: a meta-analysis. PloS One 2013;8:e74778.

31. Moazeni-Roodi A, Ghavami S, Hashemi M. Survivin rs9904341 polymorphism significantly increased the risk of cancer: evidence from an updated meta-analysis of case-control studies. Int J Clin Oncol 2019;24:335-49. 